\title{
A Case for Direct and Indirect Feedback: The Other Side of Coin
}

\author{
Hossein Hashemnezhad \\ Ph.D in TEFL, Department of English Language, Ardabil Branch, Islamic Azad University, Ardabil, Iran \\ Tel: 98-914-361-3985Ｅ-mail: h_hashemnezhad2000@yahoo.com
}

Saeed Mohammadnejad

M.A student in TEFL, Department of English Language, Ardabil Branch, Islamic Azad University, Ardabil, Iran

Tel: 98-914-807-8225 E-mail: Tefl.1982@gmail.com

Received: October 8, 2011

Accepted: October 21, 2011

Published: March 1, 2012

doi:10.5539/elt.v5n3p230

URL: http://dx.doi.org/10.5539/elt.v5n3p230

\begin{abstract}
The use of WCF is a striking necessity in learning of English as a foreign language. If teachers and students can manipulate well the use of written feedback, both parties will benefit. This research looked at the types of feedback given to EFL students during a16-week study. For the purpose of current survey eighty students enrolled freely where they were randomly assigned into two equal treatment groups. Core components of the treatment included having students write a 250 -word composition each session, and having teacher provide students with corrective feedback on their writing, and encourage students to apply what they learned in subsequent writing using feedback. According to the statistical index, the study found that CF often facilitates the student's ability to identify the existence of an error. Furthermore, the results also revealed that error feedback on form in the form of direct feedback is more beneficial than indirect feedback especially for proficient learners.
\end{abstract}

Keywords: Direct feedback, EFL, Indirect feedback, Written corrective feedback, Written corrective feedback on form

\section{Introduction}

Like many popular and influential trends of teaching, Written Corrective Feedback (WCF) is a standard method used by most teachers to provide guidance in revising students writing. In the vein of many other important and influential approaches in writing, in fact, for most writing teachers, it is the most preferred and common form of feedback (Ferris, 1997, 2007) and like many other correlated subjects in this area its effectiveness along with different types of WCF have been investigated over the last twenty years, but it is still not possible to make rigid conclusions about which options are the most beneficial to ESL learners. Due to the fact that, writing is a skill and deemed to be a booming place which promotes susceptible areas of error in an EFL circumstance, it is accepted in academic circles that feedback is an essential component in the learning cycle, providing for reflection and development. At a time when writing practices are more and more centered on enhancing students writing ability, WCF is felt to be an absolutely indispensable part of teaching writing. On the other hand, error treatment is another subject matter of a lively debate ever since which is an inseparable part of writing skill. Attitudes toward error correction have been evolved from the strict avoidance of errors before 1960s and seemed to become a helpful way in order to catch up the learners' error deficiency. Despite the fact that a lot of studies have been conducted to examine this issue (See e.g., Carroll \& Swain, 1993; Lyster, 2004; Mackey, 2000), every teacher is still following his or her own way of error feedback. The point is that for a lot of teachers their most immediate concern in the classroom is not so much to correct or not to correct, but what to correct and how to correct. The efficacy of teacher error/grammar correction in second language writing classes has been the area under discussion of much controversy wherein research on foreign and second language writing has mostly focused on how, why and how to respond to students' writing. Research evidence on error correction in L2 writing classes shows that students who receive error feedback from teachers improve accuracy over time (Ferris \& Roberts, 2001). In spite of many researches indicating to the efficacy and helpfulness of WCF (Ferris, 1999, 2003), some other works showed counter claims pointing to the body of WFC as inefficient (Truscott, 1996, 1999).

There has been controversy as to whether error feedback helps L2 students to improve the accuracy and overall quality of their writing or not (Cited in Ferris, 1999; Kepner, 1991; Truscott, 1999). The call for longitudinal 
research into the efficacy of WCF can be traced back to the debate between Truscott and Ferris in the mid to late 1990s. Truscott $(1996 ; 1999$; 2007) held a strong view against error correction arguing that all forms of error correction of L2 student writing are not only ineffective but also harmful and should be abandoned. In a 1999 study, Truscott further emphasized that although most L2 students clearly desire grammar correction, teachers should not give it to them. On the contrary, Ferris (1999) rebutted this claim by arguing that Truscott had overlooked some positive research evidence on the effects of grammar correction. Identifying the type of teacher feedback that is most appropriate and effective remains a key research question (Cited fully in Ferris, Pezone, Tade \& Tinki, 1997; Reid, 1994). Whilst feedback is an innermost aspect of $L 2$ writing programs across the world, the researchers have not been equivocally positive about its role in L2 development, and teachers often have a sense they are not making use of its full potential (Hyland and Hyland, 2006). Two types of error correction that have received attention from researchers to date are 'direct' and 'indirect' CF. The former refers to CF that supplies learners with the correct target language form when they make an error. The latter refers to various strategies (e.g. simply indicating errors) to encourage learners to self-correct their errors. Bitchener and Knoch $(2008)$ reviewed five studies that compared the effectiveness of these two types of CF (Chandler, 2003; Ferris, 2006; Lalande, 1982; Robb et al., 1986; Semke, 1984). Two studies reported no difference, two reported in favor of indirect CF and one reported in favor of direct CF.

The distinction between direct and indirect WCF makes sense in terms of language pedagogy but it is somewhat problematic when viewed from the perspective of second language acquisition theory. It is important to distinguish between two senses of acquisition (Ellis, 1994): (1) the internalisation of a new linguistic form and (2) the increase in control of a linguistic form that has already been partially internalised. It follows that the effectiveness of direct and indirect CF is likely to depend on the current state of the learners' grammatical knowledge. From a practical standpoint, however, it is unlikely that teachers will be sufficiently familiar with individual learners' interlanguages to be able to make principled decisions regarding whether to correct directly or indirectly. As Lalande (1982) and Lightbown \& Spada (1999) pointed out, such opportunities engage students at a teachable moment, that is, when they are working on their writing and are interested in the feedback they have received. Written corrective feedback focuses on two issues concurrently namely from and content.

Based on the already done studies in this field e.g. (Fully cited in Ashwell, 2000; Bitchener, 2008; Fathman \& Whalley, 1990; Ferris \& Roberts, 2001; Sheen, 2007) reporting that WCF can have an absolutely positive effect on improving students written accuracy, this study will suggest the association between noticing and marking the errors within students writing and developing their writing ability. Here, the researcher provides each student with a correct amount and type of feedback deemed to be necessary for his or her development as a writer. The contribution of written feedback to our study requires students to revise their writing in class immediately after they have received written corrective feedback on their texts is one way of training students to become more independent and therefore more responsible for the linguistic quality of their writing.

In a brief, this paper furthermore examines the published research findings on the effectiveness of these options and offers suggestions for classroom teachers designing strategies to help their L2 writers become more effective as independent learners and as critical self-editors of their texts. Best of all, the present study is looking forward to opening another horizon in introducing corrective feedback as a productive vehicle in enhancing learners competence in writing ability.

\section{Statement of the Problem}

The investigation of the annals of research in written corrective feedback has shown that it is one of the most frequently used techniques in English writing classes. Overall, based on the currently available evidence over the issue of WCF (See e.g. Ferris, 1995, 1997, 2006; Ferris \& Helt, 2000; Lalande, 1982) concluding that feedback is effective in helping EFL students improve the accuracy of their writing, it is likely to show that the present study seeks to determine whether written direct or indirect corrective feedback affect the comprehension and perception of grammatical knowledge of students' within the context of WCF. In order to discover the answers to this question, the current study is designed to testify the effects of directness type on processing of WCF. The answers to this question may be applicable to how teachers continue to speculate what degree the process of writing, provision of corrective feedback, and revision are actually helping students as they become independent writers, and hunt for empirical evidence that their own feedback can contribute optimistically to this course of action.

Also it is thought that the more we learn about corrective feedback and its correlation to L2 grammar acquisition, the more this would help our learners. By exploring which type of corrective feedback is most effective in the classroom, we hope to have better suggestions for teachers about how to provide corrective feedback to their students. Indeed, a great deal of researches has been done in order to assert the usefulness of corrective feedback or not. Some scholars 
like Truscott $(1996,1999)$ claimed that error correction alone is neutral and seems to be ineffective as well as harmful, either. Along with Truscott, Sheppard (1992) found that corrected students were no better than uncorrected students on accuracy of verb forms or on a measure of the complexity of their writing and were significantly weaker in accurately marking sentence boundaries. Despite of these studies over the inefficiency of WCF, in the meantime due to the interesting success of several studies reporting to the absolute advantage of WCF (Cited in Ashwell, 2000; Bitchener, 2008; Fathman \& Whalley, 1990; Ferris \& Roberts, 2001; Sheen, 2006, Chandler, 2000; Ferris, 1995, 1997, 2006; Ferris \& Helt, 2000; Lalande, 1982), the efficacy of feedback has been exclusively verified either immediately or in the long term.

It is important to note that, in spite of additional awareness over the issue of error correction in L2 writing, recent researches have focused on which types of error correction are more effective in treating which types of errors (Bitchener, 2008; Chandler, 2003; Ferris \& Roberts, 2001). To Hyland (2001), teacher error correction is focused on an important aspect, which is the summary comment at the end of student's assignment, whose functions serve as praises, criticisms, and suggestions. It "has largely been seen as informational, a means of channeling reactions and advice to facilitate improvements" (Hyland, 2001, p.186) and teacher's comments, as he states, "...go far beyond simple decisions to address form or content or to praise mechanics or criticize organization" (p. 208).

After almost twenty years of research and exploring error correction and communicative language teaching, researchers are still asking the same five questions:

1. Should learners' errors be corrected?

2. When should learners' errors be corrected?

3. Which errors should be corrected?

4. How should errors be corrected?

5. Who should do the correcting? (Lyster \& Ranta, 1997)

Even though we may still be a long way from answering these questions, we need to gain a better appreciation of what works in our research with learners in the hopes to inform teachers which type of corrective feedback may be useful to them.

\section{Significance of the Study}

The significance of this study lies in the fact of exploring and showing the efficacy of two types of WCF i.e. direct versus indirect feedback within a group of participants with providing feedback as well as the availability of using the feedback. Given the immense productivity of WCF (e.g. Chandler, 2000; Ferris, 1995, 1997, 2006; Ferris \& Helt, 2000; Ferris et al., 2000; Lalande, 1982), and the ever-growing popularity of it (See Ashwell, 2000; Fathman \& Whalley, 1990; Ferris \& Roberts, 2001, Sheen, 2006), all in all have persuaded us to think of WCF as a pressing phenomenon in the classroom setting, after all. Significant differences, however, were reported between various approaches toward WCF and the amount of efficacy gained through applying either direct or indirect corrective feedback. Finding logical answers based on the theoretical investigations to our research questions is the crux of the matter in this study and will make it possible for the research findings to be either replicated or generalized.

The significance of error correction in EFL situations calls for adjustments to be made to the methodology of teaching writing skill. In order to find out how the researcher can most effectively give feedback to his participants' writing in the study, it's necessary to learn the basic background information on different types of feedback the teachers give, how students make use of the feedback, and their preferences on the feedback. A number of issues regarding the significance of error correction feedback on ESL student writing have been investigated, but it is evenly clear that in our study we need to examine the effects of corrective feedback as the following: (1) on new piece of writing tasks or drafts, (2) on three linguistic error categories, (3) with intermediate learners, in an academic setting. In order to start addressing these needs, the following 16-week study was undertaken with 80 post-intermediate students at an Iranian university to investigate the extent to which corrective feedback on targeted linguistic forms under different treatment conditions helped students improve the accuracy of new pieces of writing.

\section{Research Questions and Hypotheses}

The present study follows this line of research by examining direct correction and indirect feedback in second language writing, with an emphasis on how different types of grammatical errors can be treated. With these considerations in mind, we are prepared to form our research questions. Though the following questions are being stated generally here, they will be defined and answered operationally in the subsequent chapters. Three questions are addressed in this study: 
1. Does indirect written corrective feedback have any effect on learning English grammatical types (form not content) in Iranian EFL writing classes?

2. Does direct written corrective feedback have any effect on learning English grammatical types (form not content) in Iranian EFL writing classes?

3. Do students who receive direct written corrective feedback outperform those who receive indirect corrective feedback?

In this study, three stated hypotheses will be tested as the below:

1. Teacher's written direct feedback on grammatical errors has influence on students' writing ability.

2. Teacher's written indirect feedback on grammatical errors leads to more accurate performance on students' writing ability.

3. Students' at direct corrective feedback group do better than students at indirect feedback group.

It seems that as our concrete hypothesis, if learners of English as L2 get explicit instruction in their writing course, say, corrective feedback, it may affect on their writing ability, and helps them to be more proficient writers than before. The hypotheses of our survey indicate that students may need advice on understanding and using feedback before they can engage with it.

\section{Method}

This section summarizes the methodology being used in this research specially with exploring the use of feedback as a methodology in teaching writing to EFL students. It will begin with a description of the participants involved including students and researcher who scored and rated various aspects of the student writing. It will move on the second section which will describe different instruments used to record the data for the study, including the program designed specifically for this project. The third section will explain the type of procedure used and the final section will illustrate the research design as a brief rationale, including an explanation of the design for establishing evidence of reliability beside the research variables.

Having been compared with earlier studies on the significance of written corrective feedback (Ferris 2003), in which as many as 15 linguistic forms and structures had been examined to show the value of $\mathrm{CF}$, the present study aimed to investigate the effect of targeting a few functional uses of the grammatical features in English: simple past tense, relative pronouns, and preposition. These mentioned linguistic forms and structures were targeted because it was assumed that students studying English language had experienced difficulty in the use of them, repetitively. In other words, this chapter covers the population, instruments, the procedures of data collection, research design and research variables respectively.

\subsection{Participants}

The whole participants included in this study were 80 Iranian students chosen from a pool of 140 students studying in their 3rd year of undergraduate education and participated voluntarily in this study within two experimental groups. Unlike most error correction studies done so far (Ashwell, 2000; Bitchener 2008; Carol \& Swain, 1993; Ferris, 2003; 2007) which had focused on more advanced learners, students who enrolled in this study were junior and they all consisted of 80 intermediate students who had just passed their second year of college. Students who enrolled in English Translation Course at Payameh-nor University were selected as participants for this study in which they were predominately studying English as their major. Two groups of participants were involved as direct and indirect corrective feedback groups. Since our participants had all passed their writing course II successfully, it did not need to conduct any test such as a placement test in order to measure their ability in writing. As a result, they were chosen for the data collection process.

Additionally, the native language (L1) of the participants in this study was mainly Azeri. The dispersion of the population was as the following; of these participants, 35 were male and the rest were 45 female students and their ages ranged from 19 to 26 . This study attempted to discover if learners could gain greater control over a target structure after receiving any form of CF.

\subsection{Instrumentations and Procedure}

To situate student reactions in the specific context in which feedback was provided, the present study put together a number of instruments that were used in assessing the degree of feedback the researcher casted over the students' papers. The instruments had been carefully chosen to answer the three research questions of the study. In order so, four instruments were utilized in this study: a text book, two different types of corrective feedback, as well as a final exam or post-test. These instruments were chosen according to the needs and demands of the study. Together, the 
above multiple sources of instruments were seemed to throw light on the teachers' feedback practices and how student reactions could be interpreted within their specific contexts.

This study was carried out in an academic term and consisted of a number of stages such as selection of participants from a pool of students, sampling and finally assigning them into appropriate groups. Before moving on to each individual stage, the students were provided with all the necessary instructions relevant to the procedure. In the stage of selection, 80 students were randomly selected out of 140 students for the present study and they were randomly assigned into two different treatment groups each consisting of 40 participants through sampling procedure i.e., one experimental group with direct feedback and another experimental group with coded feedback. Group A, the group of 40 participants, received direct written corrective feedback on the targeted features. Group B, another group of 40 participants received coded indirect written feedback. Subsequently, one experimental group received direct corrective feedback and the other experimental group received coded indirect corrective feedback. All the compositions were provided with feedback, direct corrective feedback took the form of identifying both the error and the target form (Table 1), and indirect corrective feedback was used in the form of codes on form (Table 2) in which the researcher made use of a coding scheme that indicated the students error i.e., such as the errors related to verb tense, prepositions and relative pronoun in which students were supposed to correct the errors themselves.

\subsubsection{Text Book}

The text book implemented in this study named Academic Writing Course written by R. R. Jordan (1980) which chiefly focused on teaching the preliminary steps of writing course in an academic situation from paragraph structuring to essay writing through a process approach. For the purpose of the present research, twelve units were selected and taught consecutively. From a general perspective, this book has been designed to take university-level students with an intermediate ability in English as a second language (L2) from paragraph writing through essay writing. The main theme of text book is to teach both how to get ready to write coherently and how to identify the basics of writing, as well as putting them into practice simultaneously. The areas covered in the text book included generating ideas, organizing, drafting, reviewing and revising. This text book provided participants with a variety of writing tasks. It also offered them various models of writing that were based on real assignments.

\section{Research Methodology}

Since the concept of experimental method is an idealized abstraction, and meanwhile this study could not meet all the necessary requirements to be an experimental research design such as randomization procedure in which asking participants to serve as a control group was somehow impossible the current study due to such certain limitations inclined to choose a quasi-experimental research design. In addition, according to the number of applicants who wanted to participate in this research project and due to the fact that selecting subjects form this pool was laborious and time-consuming a list of qualified subjects was provided on the basis of the proportion of the subjects in the population. Owing to the fact that selecting the sample was based on the assumption in which the probability of each subject being drawn was not known, the study chose a non-random sampling. After determining the type of sampling procedure, it was the right time to specify the selection process in which the participants were chosen from a whole of population. Because this study was based on a quasi-experimental research design, and on the other hand the presence of some limitations the study preferred to take on a typical sampling procedure called purposive sampling where a certain number of participants was collected with determined characteristics such as their tendency to participate in the study where their writing skills would be analyzed and will be judged according to their performance.

\subsection{Research Variables}

\section{Independent variable}

The independent variables of this study were two kinds of written feedback besides a writing instruction and the research method which were used to show the degree of and variation in achievements of students. There were two feedback conditions: direct corrective feedback, indirect corrective feedback i.e., coded feedback.

\section{Dependent variable}

The dependent variable of this study was students' degree of enhancements after two forms of feedback were administered and operationalized. This achievement was the result and effect of the teacher instruction. This construct was achieved subsequently after students received feedbacks and showed improvement in their writing tasks during the total period of research implementation. Students in two experimental groups wrote their writing tasks every session and received two forms of feedback according to their classification.

\section{Control variable}

The control variables included in this study were held in order to neutralize the potential effect it might have on the 
outcome of study. There were two covariates included in this study: the language background of students from two groups and the length of study which was intentionally controlled to reduce its effects on the results.

\section{Intervening variable}

Since none of the intervening variables could neither be measured nor manipulated in any research study, it cannot affect the study directly. The intervening variables of this study were students' intelligent, learning, and frustration after writing tasks which was resulted from teacher's feedback.

\section{Moderator variable}

The moderator variable was included in this research and it modified the relationship between the independent variable and dependent variable. For this study, the moderator variable was the inclusion of students' sex factor. This variable was selected in order to investigate whether the results of study were modified because of this variable or not.

\section{Results}

In order to evaluate the obtained data, we made a great use of t-test statistical technique with two feedback conditions, i.e., direct corrective feedback and indirect corrective feedback, as independent variables and students' degree of enhancements after two forms of feedback as dependant variable. Table 3 shows the frequency of errors in three form areas for direct WCF group. Comparison of the Mean scores of four writing occasions showed that on grammatical category of verb tense students in post-test 2 made the least number of errors (Mean=1.32). In addition, comparing the mean scores of this group reveals that students in post-test 1 had the least number of errors over grammatical category of preposition (Mean=1.8). And finally, it shows that students in post-test 2 over relative pronouns was better and had the least number of errors (Mean=.77). As it can be seen in Table 3, for most of the error types committed by direct feedback groups, there is a steady decrease within the course of the semester. The final result shows that by the end of the study there is decrease for 3 error types for direct feedback group which includes verb form tense from (9.15 to 1.32), relative pronoun from (5.9 to .77), and preposition from (12.65 to 1.22).

According to these statistics, it can be inferred that students' improvement at the second post-test was stable. This provides an appropriate measure for students to increase their accuracy of writing. Comparing the frequency of errors obtained from total compositions, there was a consistent fluctuation in the number of errors among three grammatical areas. It should be noted that, students initially demonstrated poor control over the use of CF. This inconsistency was disappeared gradually when they received corrective feedback and put it into practice at their subsequent writings.

Table 4 shows the descriptive statistics for direct CF group at the four different testing periods; (draft one, draft two, post-test one, and post-test two). This table provides the representation of the Mean percentages for the four testing periods for each group. The Mean scores refer to the Mean percentage accuracy in different occasions. According to this table, while the two groups were dissimilar at time one and two (the first and second draft), they significantly increased accuracy after treatment, i.e., CF was given (post-test one and two). These statistics support the findings in Table 1.4 in the sense that while the adjusted average numbers of errors for direct feedback group was 27.72 for the first draft, 16.92 for the second draft, 4.32 for post-test one, and 3.3 for post-test two. According to these numbers, it shows that students were able to retain most of this improvement after treatment was provided in each testing time.

Table 5 also displays the frequency of errors for indirect WCF group over three grammatical areas. In the statistics above, we can see that the mean score of students in post-test 2 over verb tense category was smaller and so they made the least number of errors (Mean=1.27). Comparison of the mean scores show that on grammatical category of preposition students in post-test 2 made the least number of errors (Mean=1.37). And finally, it shows that students in post-test 2 over relative pronouns was better and had the least number of errors (Mean=1.3). According to these statistics, it can be inferred that students' improvement at the second post-test was stable. As a result, this provides an appropriate measure for students to increase their accuracy of writing. The final result shows that by the end of the study there is decrease for 3 error types for direct feedback group which includes verb form tense from (11.37 to 1.27), relative pronoun from (7.55 to 1.3), and preposition from (13.52 to 1.37).

According to Table 6 which demonstrates the descriptive statistics for indirect WCF group while the adjusted average number of errors for total draft one was 32.2, 18.8 for total draft two, 6.07 for total post-test one, and 3.95 for total post-test two. According to this statistics, there is a perceptible sign of error reduction in indirect WCF group. This situation is reported descending for this group.

And finally, Table 7 shows the Means and standard deviations as well as standard error means for the error correction obtained from analyzing the data in each group. The same 80 students were included in this analysis each 
group including 40 participants. Comparison of the mean scores of these two groups shows direct WCF group outperformed indirect WCF group in which feedback was given indirectly in the form of marking codes. In order to show the difference in the number of errors marked in each group, frequency of total errors was run through descriptive statistics explaining that respondents in Group A, who received direct form of written feedback such as insertion, deletion, and substitution, outperformed those who received indirect written feedback in the form of codes. Students in Group A showed the minimum number of errors in total of drafts with a Mean error 52.27. This difference can be seen for Group B with a Mean error of 61.02. The number of mean errors showed that Group A used direct feedback to reduce the number of errors in their drafts, whereas Group B was not as good as Group A to reduce the errors in their drafts.

To answer the first research question, the results obtained from feedback conditions revealed that the two kinds of corrective feedback had a positive effect on students' target language accuracy but direct feedback had a much more effect than indirect feedback. This finding is along with Ferris $(1999 ; 2002 ; 2004)$ who makes a stand for the use of error correction in writing classes. Some classroom studies conducted in a range of instructional settings have demonstrated that WCF had a positive effect on improving students' written accuracy (Ashwell, 2000; Bitchener, 2008; Fathman \& Whalley, 1990; Ferris \& Roberts, 2001; Sheen, 2006).

The answer for research question two can be answered through obtaining data from the inferential statistic indexes. Comparing the mean scores of both groups, we saw that direct corrective feedback group outperformed the indirect corrective feedback as a result the difference in the mean scores was statistically significant in alpha level of .05. This study proved that both forms of corrective feedback are effective with L2 grammar acquisition with an advantage for direct feedback, though.

The data for the research question three were gained in which average number of errors marked in total of drafts was plummeted dramatically. Providing the precise and accurate feedback resulted in positive responses from the respondents in the subsequent drafts. A careful conclusion to our third research question on the relative enhancement of students' performance of writing after feedback is that direct error correction seems to be more effective than indirect error correction.

\section{Discussion and Conclusion}

Truscott's review of studies by Kepner (1991), Semke (1984), and Sheppard (1992) claimed that error correction does not have a noteworthy effect on improving L2 student writing. Considering this limited range of studies, the present study sought to find out the efficacy of two different types of feedback on the accuracy performance of three targeted linguistic error categories in writing classes. The study found that the type of feedback provided did have a significant effect on accuracy. From this finding, we could easily jump to the conclusion that Truscott (1996) was not right with our findings when he claimed that the provision of corrective feedback on L2 writing is ineffective. The results of our investigation into the effects of different types of feedback on individual linguistic features suggests that this type of examination is more fruitful because it acknowledges the fact that different linguistic categories represent detached domains of knowledge and that they are acquired through different stages and processes (Ferris, 1999, 2002; Truscott, 1996).

The present study found that the type of feedback provided had a significant effect on the accuracy with which the participants used the separate linguistic categories in new pieces of writing. The provision of direct written feedback together with indirect written feedback resulted in significantly greater accuracy when the past simple tense, relative pronoun and the preposition were used in new pieces of writing or drafts. In order to contribute to the need for further research on the value of providing corrective feedback to L2 writers (Ferris, 1999; Truscott, 1996), the present study investigated the extent to which different types of feedback on three targeted error categories helped L2 writers improve the accuracy of their use in new pieces of writing. It found that written corrective feedback especially direct feedback enabled them to use the past simple tense, relative pronoun and the preposition with significantly greater accuracy in new pieces of writing. This finding adds to a growing body of research that has investigated the effect of different feedback strategies on accuracy performance.

Based on the findings of this research, it can be concluded that there are some defensible reasons to support error feedback in writing. Some researchers argue that error feedback does not help learners develop grammatical accuracy in writing (Truscott, 1996). This view seems to be premature because most of the studies were cross-sectional in nature, so it takes a substantial time for learners to internalize forms of language after feedback. Furthermore, teacher error feedback might have a delayed effect on students' developmental status of writing. When discussing error feedback in writing, researchers need to clarify which learners they are talking about and what stage of learning they are dealing with. Error feedback benefits adults more than children. As shown in the results of the study, majority of learners believed errors as hurting their accuracy of writing. Error feedback seems to have the 
strongest effect in the editing phase rather than composing or revising which correspond to the literature (Bitchener and Knoch, 2008; Chandler, 2003; Ferris, 2002; Sheen, 2007).

\section{References}

Ashwell, T. (2000). Patterns of teacher response to student writing in a multiple-draft composition classroom: Is content feedback followed by form feedback the best method. Journal of Second Language Writing, 9(3), 227-257. http://dx.doi.org/10.1016/S1060-3743(00)00027-8

Bitchener, J. (2008). Evidence in support of written corrective feedback. Journal of Second Language Writing, 18(2), $181-201$

Bitchener, J., \& U. Knoch. (2008). The relative effectiveness of different types of direct written corrective feedback. System, 37, 322-29. http://dx.doi.org/10.1016/j.system.2008.12.006

Carroll, S., \& Swain, M. (1993). Explicit and implicit negative feedback: An empirical study of the learning of linguistic generalizations. Studies in Second Language Acquisition, 15, 357-366. http://dx.doi.org/10.1017/S0272263100012158

Chandler, J. (2000). The efficacy of error correction for improvement in the accuracy of L2 student writing. In: Paper presented at the AAAL conference, Vancouver, BC.

Chandler, J. (2003). The efficacy of various kinds of error feedback for improvement in the accuracy and fluency of L2 student writing. Journal of Second Language Writing, 12(3), 267-296. http://dx.doi.org/10.1016/S1060-3743(03)00038-9

Ellis, R. (1994). The study of second language acquisition. Oxford University Press.

Fathman, A., \& Whalley, E. (1990). Teacher response to student writing: Focus on form versus content. In B. Kroll (Eds.), Second language writing: Research insights for the classroom. (pp. 178-190). Cambridge: Cambridge University Press.

Ferris, D. R. (1995). Student reactions to teacher response in multiple-draft composition classrooms. TESOL Quarterly, 29, 33-48. http://dx.doi.org/10.2307/3587804

Ferris, D. R. (1997). The influence of teacher commentary on student revision. TESOL Quarterly, 31, 315-339. http://dx.doi.org/10.2307/3588049

Ferris, D. R. (1999). The case for grammar correction in L2 writing classes: A response to Truscott (1996). Journal of Second Language Writing, 8(4), 1-11. http://dx.doi.org/10.1016/S1060-3743(99)80110-6

Ferris, D. R. (2002). Treatment of error in second language writing. Ann Arbor: The University of Michigan Press.

Ferris, D. R. (2003). Response to student writing: Implications for second language students. Mahwah, NJ: Lawrence Erlbaum Associates.

Ferris, D. R. (2004). The Grammar Correction debate in L2 writing: Where are we, and where do we go from here? (and what do we do in the meantime. . .?). Journal of Second Language Writing, 13, 49-62. http://dx.doi.org/10.1016/j.jslw.2004.04.005

Ferris, D. R. (2006). Does error feedback help student writers? New evidence on the short- and long-term effects of written error correction. In K. Hyland, \& F. Hyland (Eds.), Feedback in second language writing: Contexts and issues. (pp. 81-104). Cambridge: Cambridge University Press.

Ferris, D. R. (2007). Preparing teachers to respond to student writing. Journal of Second Language Writing, 16, 165-193. http://dx.doi.org/10.1016/j.jslw.2007.07.003

Ferris, D. R., \& Helt, M. (2000). 'Was Truscott right? New evidence on the effects of error correction in L2. writing classes'. Paper presented at the American Association of Applied Linguistics Conference, Vancouver, B.C., March.

Ferris, D. R., Pezone, S., Tade, C. R., \& Tinki, S. (1997). Teacher commentary on student writing: descriptions \& implications. Journal of Second Language Writing, 6(2), 155-182. http://dx.doi.org/10.1016/S1060-3743(97)90032-1

Ferris, D., \& Roberts, B. (2001). Error feedback in L2 writing classes: how explicit does it need to be? Journal of Second Language Writing, 10(6), 161-184. http://dx.doi.org/10.1016/S1060-3743(01)00039-X

Hyland, F., \& Hyland, K. (2001). Sugaring the pill Praise and criticism in written feedback. Journal of Second Language Writing, 10(3), 185-212. http://dx.doi.org/10.1016/S1060-3743(01)00038-8

Hyland, F., \& Hyland, K. (2006). Feedback on second language students' writing. Language Teaching, 39(10), 
83-101. http://dx.doi.org/10.1017/S0261444806003399

Kepner, C. G. (1991). An Experiment in the relationship of types of written feedback to the development of second-language writing skills. The Modern Language Journal, 75(3), 305-313. http://dx.doi.org/10.2307/328724

Lalande, J. F. (1982). Reducing composition errors: An experiment. The Modern Language Journal, 66(2), 140-149. http://dx.doi.org/10.2307/326382

Lightbown, P., \& Spada, N. (1999). Focus on form and corrective feedback in communicative language teaching: Effects on second language learning. Studies in Second language Acquisition, 12(4), 429-448. http://dx.doi.org/10.1017/S0272263100009517

Lyster, R. (2004). Research on form-focused instruction in immersion classrooms: Implications for theory and practice. Journal of French Language Studies, 14, 323-341. http://dx.doi.org/10.1017/S0959269504001826

Lyster, R., \& Ranta, L. (1997). Corrective feedback and learner uptake: negotiation of form in communicative classrooms. Studies in Second Language Acquisition, 19, 37-66

Mackey, A. (2000). Input, interaction, and second language development: An empirical study of question formation in ESL. Studies in Second Language Acquisition, 21, 557-587

Reid, J. (1994). Responding to ESL students' texts: the myths of appropriation. TESOL Quarterly, 28(5), 273-292. http://dx.doi.org/10.2307/3587434

Robb, T., Ross, S., \& Shortreed, I. (1986). Salience of feedback on error and its effect on EFL writing quality. TESOL Quarterly, 20, 83-91. http://dx.doi.org/10.2307/3586390

R. R. Jordan. (1980). Academic Writing Course (1st ed.). London: Collins ELT.

Semke, H. (1984). The effect of the red pen. Foreign Language Annals, 17, 195-202. http://dx.doi.org/10.1111/j.1944-9720.1984.tb01727.x

Sheen, Y. (2006). Exploring the relationship between characteristics of recasts and learner uptake. Language Teaching Research, 10, 361-392. http://dx.doi.org/10.1191/1362168806lr203oa

Sheen, Y. (2007). The effect of focused written corrective feedback and language aptitude on ESL learners' acquisition of articles. TESOL Quarterly, 41, 255-283

Sheppard, K. (1992). Two feedback types: Do they make a difference? RELC Journal, 23, 103-110. http://dx.doi.org/10.1177/003368829202300107

Truscott, J. (1996). The case against grammar correction in L2 writing classes. Language Learning, 46, 327-369. http://dx.doi.org/10.1111/j.1467-1770.1996.tb01238.x

Truscott, J. (1999). The case for "the case for grammar correction in L2 writing classes": A response to Ferris. Journal of Second Language Writing, 8(4), 111-122. http://dx.doi.org/10.1016/S1060-3743(99)80124-6

Truscott, J. (2007). The effect of error correction on learners' ability to write accurately. Journal of Second Language Writing, 16(7), 255-272. http://dx.doi.org/10.1016/j.jslw.2007.06.003

Table 1. Examples of direct corrective feedback.

Example 1: Deletion
When I am a child, my father take me to school by his car.
was took
Example 2: Insertion
to an
Professor Johnson asked us ${ }^{\wedge}$ write ${ }^{\wedge}$ other essay to make up our low grades.
Example 3: Substitution
To them, this country is the place to seek a more apprepriate-future.

Note: From "Error feedback in L2 writing classes ", by D. Ferris et al., 2000, Journal of Second Language Writing, how explicit does it need to be? 10(6), 161-184. 
Table 2. Examples of indirect corrective feedback.

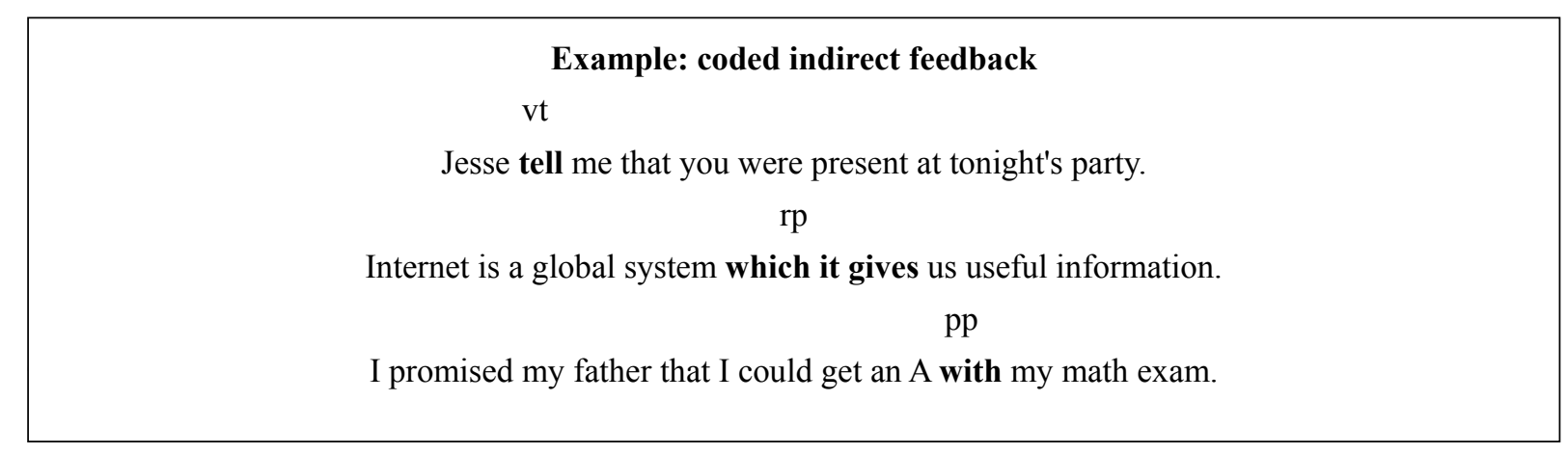

Note: $\mathrm{vt}=$ Wrong verb tense; $\mathrm{rp}$ : Wrong relative pronoun; $\mathrm{pp}=$ Wrong preposition. Sample codes $\&$ definitions taken from Ferris et al. (2002).

Table 3. Group one (Direct written corrective feedback): Frequency of errors in three form areas

\begin{tabular}{lccc}
\hline Testing time & $\begin{array}{c}\text { Mean } \\
\text { Verb tense }\end{array}$ & $\begin{array}{c}\text { Mean } \\
\text { Preposition }\end{array}$ & $\begin{array}{c}\text { Mean } \\
\text { Relative pronoun }\end{array}$ \\
\hline Draft 1 & 9.15 & 12.65 & 5.9 \\
Draft 2 & 5.92 & 7.55 & 3.65 \\
Post-test 1 & 1.47 & 1.8 & 1.2 \\
Post-test 2 & 1.32 & 1.22 & .77 \\
\hline
\end{tabular}

Table 4. Descriptive statistics by categories corrected for direct feedback group

\begin{tabular}{|c|c|c|c|c|c|c|c|c|c|}
\hline \multirow[t]{2}{*}{ Group } & \multirow[t]{2}{*}{$\mathrm{N}$} & \multicolumn{2}{|c|}{ Time 1} & \multicolumn{2}{|c|}{ Time 2} & \multicolumn{2}{|c|}{ Time 3} & \multicolumn{2}{|c|}{ Time 4} \\
\hline & & $\mathrm{M}$ & $\mathrm{SD}$ & $\mathrm{M}$ & SD & $\mathrm{M}$ & $\overline{\mathrm{SD}}$ & M & SD \\
\hline Direct CF & 40 & 27.72 & 7.28 & 16.9 & 6.03 & 4.32 & 2.23 & 3.3 & 2.06 \\
\hline
\end{tabular}

Table 5. Group two (Indirect written corrective feedback): Frequency of errors in three form areas

\begin{tabular}{lccc}
\hline Testing time & $\begin{array}{c}\text { Mean } \\
\text { Verb tense }\end{array}$ & $\begin{array}{c}\text { Mean } \\
\text { Preposition }\end{array}$ & $\begin{array}{c}\text { Mean } \\
\text { Relative pronoun }\end{array}$ \\
\hline Draft 1 & 11.37 & 13.52 & 7.55 \\
Draft 2 & 7.05 & 7.55 & 4.42 \\
Post-test 1 & 1.57 & 2.67 & 1.82 \\
Post-test 2 & 1.27 & 1.37 & 1.3 \\
\hline
\end{tabular}

Table 6. Descriptive statistics by categories corrected for indirect feedback group

\begin{tabular}{|c|c|c|c|c|c|c|c|c|c|}
\hline \multirow[t]{2}{*}{ Group } & \multirow[t]{2}{*}{$\mathrm{N}$} & \multicolumn{2}{|c|}{ Time 1} & \multicolumn{2}{|c|}{ Time 2} & \multicolumn{2}{|c|}{ Time 3} & \multicolumn{2}{|c|}{ Time 4} \\
\hline & & $\mathrm{M}$ & $\mathrm{SD}$ & $\mathrm{M}$ & $\mathrm{SD}$ & $\mathrm{M}$ & SD & $\mathrm{M}$ & $\mathrm{SD}$ \\
\hline Indirect $\mathrm{CF}$ & 40 & 32.2 & 10.35 & 18.8 & 5.91 & 6.07 & 3.2 & 3.95 & 1.88 \\
\hline
\end{tabular}

Table 7. Group statistics (Means, std. Deviation, and Std. Error Mean)

\begin{tabular}{|c|c|c|c|c|}
\hline GROUP & N & Mean & Std. & Std. Error \\
\hline Direct feedback & 40 & 52.2750 & 10.30804 & 1.62984 \\
Indirect feedback & 40 & 61.0250 & 15.63279 & 2.47176 \\
\hline
\end{tabular}

